\title{
Kyynelkanavat
}

\author{
Nykyajan itkuvirret ja itkuvirsiperinteen merkitykset modernissa suomalaisessa \\ yhteiskunnassa
}

Hanke-esittely

Elina Hytönen-Ng, Riikka Patrikainen, Viliina Silvonen

\begin{abstract}
Tyynelkanavat-hanke tarkastelee tieteen ja taiteen keinoin itkuvirsiperinteen jatkumoa Lja roolia modernissa yhteiskunnassa. Hankkeessa etsimme vastausta kysymykseen, minkälaisiin tarpeisiin itkuvirret ja äänellä itkeminen nykymaailmassa vastaavat? Hankkeessa työskentelee kolme taiteilija-tutkija-työparia, jotka lähestyvät aihetta kokemuksellisuuden, uskonnollisuuden, yhteisöllisyyden ja tunteen näkökulmista. Hankkeessa folkloristiikan, etnomusikologian ja kulttuurintutkimuksen näkökulmat yhdistyvät taiteen tapoihin lähestyä ja soveltaa itkuvirsiperinnettä. Kyynelkanavat on Koneen Säätiön rahoittama kolmivuotinen hanke, joka alkoi 1.4.2021.
\end{abstract}

Nyky-Suomessa itkuvirret juontuvat itämerensuomalaisista, etenkin karjalaisesta ja inkeriläisestä perinteestä. Itkuvirret olivat etenkin hautajais- ja häärituaaleihin kuuluvaa laulettua runoutta. Itkijänaisen tehtävä oli mahdollistaa vainajalle itkuvirsien avulla turvallinen siirtyminen tuonpuoleiseen. Myyttisten käsitysten mukaan kuolleet kuulivat itkuvirret, ja itkuvirsien ilmaisussa heijastuukin lämmin ja kunnioittava suhde tuonpuoleista kohtaan. Rituaalisissa tilanteissa itkuvirret kanavoivat koko yhteisön surua, mutta itkuvirsin voitiin purkaa myös muita yksityisempiä tai arkisempia huolia ja murheita. (Honko 1963; Nenola-Kallio 1982; Konkka 1985; Jetsu 2013; Stepanova 2014.) Rituaalinen, myyttistä maailmankuvaa heijastava perinne on hiipunut kulttuurisen ja sosiaalisen kontekstien muuttuessa. Vaikka itkuvirsiperinteen katoamisesta on kirjoitettu jo pitkään, elää se yhä 2000-luvun Suomessa. Kiinnostus itkuvirsiä ja äänellä itkemistä kohtaan on kasvanut useamman vuosikymmenen ajan. Itkuvirsikurssit keräävät paljon osallistujia eri puolilla Suomea, ja perinnettä sovelletaan esittäviin taiteisiin ja yhdistetään erilaisiin musiikkityyleihin. (Tenhunen 2006; Wilce 2009; Fenigsen \& Wilce 2012.) Näitä erilaisia vakiintuneen aseman saavuttaneita perinteen nykymuotoja on nyt varsin hedelmällistä tutkia.

Karjalaisessa ja inkeriläisessä kulttuurissa itkuvirret ovat olleet nimenomaan sosiaalisesti ja kulttuurisesti sallittu julkisen itkemisen ja suremisen muoto. Tällainen sosiaalisesti ja kulttuurisesti hyväksytyn itkemisen tarve ei ole hävinnyt modernista yhteiskunnasta. Nykyisessä kulttuurissa itkemiseen kuitenkin liittyy usein häpeää (esim. Wilce 2009). Vaikka viime vuosina 
julkinen itkeminen on muuttunut aiempaa sallitummaksi, julkisesti itkemistä pyydetään usein edelleen anteeksi. Kyynelkanavat-hankkeessa tarkastelemme, miten nykyajan itkuvirret vastaavat ja asettuvat tähän kenttään.

Kyynelkanavat-hankkeessa järjestämme vuosittain itkuvirsiin ja äänellä itkemiseen keskittyviä tapahtumia. Tapahtumien tavoitteena on luoda kohtaamispaikka kaikille itkuvirsistä kiinnostuneille. Tapahtumissa tuodaan tutkija-taiteilija-työparien teemoja esille ja käydään keskustelua niin tutkimuksen kuin äänellä itkijöidenkin kentän kanssa.

\section{Hankkeen tavoite}

Nykyajassa itkuvirsiperinne on versonut moniin eri suuntiin ulottuen taiteesta terapiaan. Tutkimuksemme pääkysymyksiä ovatkin, mitä kaikkea itkuvirret nykyaikana ovat ja minkälaisia merkityksiä itkuvirsille ja äänellä itkemiselle annetaan. Hankkeemme tavoitteena on tutkia nykyitkuvirsiperinteen laajaa kenttää ja tuoda esille, miten moninaisista ilmiöstä se muodostuu. Näitä ilmiöitä ovat esimerkiksi aiheeseen liittyvä lisääntynyt tutkimus, itkuvirret osana taiteita sekä itkuvirsikurssien ja ohjattujen itkupiirien myötä koko ajan kasvava harrastajayhteisö.

Itkuvirsissä yhteisöllisyys on ollut keskeinen elementti. Itkuvirsillä on ilmaistu eroon liittyvää ikävää sekä surtu kollektiivisesti. Lauri Honko kuvaakin itkuvirsiä ikuisen eron runoutena (1963, 82). Itkuvirsissä esitettyjen tunteiden kirjoon liittyy voimakkaasti kaipuun ja ikävän sävyjä, mutta myös lämpimiä muistoja ja kiitollisuutta. Itkujen kautta on voitu nostaa esiin myös epäkohtia ja esittää kritiikkiä. Vaikka itkuvirsien taustalla ei enää ole yhtenäiskulttuuria, jota vasten itkujen yhteisölliset merkitykset rakentuvat, yhteisöllisyys on edelleen läsnä itkuvirsiperinteessä. Hankkeessa tarkastelemmekin nykyitkuvirsiin liittyvää yhteisöllisyyttä ja sen merkityksiä.

Kyynelkanavat-hankkeen tutkimuksellinen metodologia nousee osallistuvasta etnografiasta. Havainnoinnin ja haastattelujen rinnalla metodologisina välineinä toimivat auto- ja aistietnografia. Lähestymistavoissa painottuvat kokemuksellisuus, tunteet ja affektiivisuus. Teoreettisessa viitekehyksessä tulevat esiin hankkeen tutkijoiden erilaiset taustat ja kiinnostuksen kohteet.

Hankkeen työparit ovat Elina Hytönen-Ng ja Emilia Kallonen, Riikka Patrikainen ja Liisa Matveinen sekä Viliina Silvonen ja Emmi Kuittinen. Jokaisella työparilla on oma teemansa ja näkökulmansa, joiden ympärille työparin yhteistyö keskittyy. Työparien teemat sekä tukevat että täydentävät toisiaan.

\section{Tutkija-taiteilija-työparit}

Etnomusikologi, kulttuurintutkija, FT, dosentti Elina Hytönen-Ng ja kansanlaulaja, musiikkipedagogi (amk), Äänellä itkijät ry:n puheenjohtaja Emilia Kallonen ovat työryhmän yksi työpari. Heidän työskentelyssään korostuu äänellä itkemisen luovan, omakohtaisen ja kehollis-emotionaalisen prosessin tutkiminen itkijän ja itkutilanteen näkökulmasta työparin yhteistyössä sekä itkuvirsikursseilla. Työpari korostaa tutkijan omakohtaista osallistumista ja autoetnografiaa.

Kallosen ja Hytönen-Ng:n työpari keskittyy tarkastelemaan itkuvirsikursseja, sillä äänellä itkemisen voidaan todeta elävän nykypäivänä pitkälle näiden kurssien välityksellä. Kurssien kautta 
äänellä itkeminen on kenen tahansa kiinnostuneen ulottuvilla, ja kuka vain voi halutessaan opetella taitoa, tehdä omia itkuja ja jakaa niitä omissa yhteisöissä. Vaikka "itkuharrastus" on edelleen marginaalissa, se kerää kuitenkin vuosittain satoja kiinnostuneita kursseille ympäri Suomea. Työparin työskentelyn keskiössä on yhteinen jaettu ja henkilökohtainen äänellä itkun luova prosessi, jota avataan myös ulospäin kirjoittamalla.

Kulttuurintutkija, TM Riikka Patrikainen ja kansanmuusikko, MuM Liisa Matveinen muodostavat hankkeessa työparin, jonka yhteistyön tavoitteena on tutkia kirkollisen perinteen ja kansanperinteen rinnakkaisuutta nykyitkuissa. Itkuvirsien esittäminen on perinteisesti ollut erityisesti idän kirkon vaikutuspiirissä säilynyttä perinnettä ja tätä taustaa vasten on perinteitä mahdollista myös tutkia osin samoja merkityksiä kantavana. Työpari tuottaa uutta tietoa siitä, miten perinteiden rinnakkaisuus on havaittavissa myös karjalaisesta perinteestä ammentavan, ortodoksin nykyitkijän esittämissä vainajien muisteluitkuissa ja siitä, miten nykyitkijän oma maailmankatsomus vaikuttaa siihen minkälaisia merkityksiä hän itkuvirsille ja erityisesti kuolinitkuille antaa.

Matveinen on aloittanut esittävän itkuvirsiperinteen tutkimisen Sibelius-Akatemiassa jo 1980-luvulla ja toiminut vuodesta 1998 äänellä itkun kouluttajana. Hänen periaatteitaan äänellä itkemisessä ovat muun muassa suomen kielen käyttö alkuperäisen karjalaisen itkukielen sijaan. Hän kuitenkin käyttää itkuvirsissään karjalaisen itkuvirsikielen tyylikeinoja, kuten metaforia, alkusointua ja vapaata runomittaa. Matveinen on kotoisin llomantsista, jossa hänellä on ollut mahdollisuus tutustua karjalaistaustaisiin, nyt jo edesmenneisiin itkijöihin henkilökohtaisesti 1980-luvulla. Patrikainen taas on taustaltaan ortodoksikanttori, joka tutkii poikkitieteellisessä väitöskirjassaan ortodoksisen kirkon hautajaiskäytänteiden, erityisesti hautajaisveisujen suhdetta kreikkalaisiin ja karjalaisiin kansanomaisiin hautajaisrituaaleihin, erityisesti itkuvirsiin.

Folkloristi, FM Viliina Silvosen ja kansanmuusikko, MuM Emmi Kuittisen muodostama työpari tarkastelee nykyitkuvirsien konteksteja ja käytäntöjä etenkin tunteiden, yhteisöllisyyden ja esityksen näkökulmista sekä hahmottelee nykyitkujen asettumista itkuperinteen jatkumolle. Teemat kietoutuvat itkujen moninaisuuteen perinteisestä rituaalisesta käytännöstä nykyajan esittäväksi taiteeksi. Perinne nähdään menneen ja nykyisyyden välisenä prosessina, joka luo uusia ja jatkuvasti muuttuvia merkityksiä.

Kuittinen on itkuvirsiperinteeseen erikoistunut kansanmuusikko. Hänellä on perinnettä kunnioittava mutta rohkeasti uudistava, taiteellinen ote äänellä itkemiseen. Silvonen on perehtynyt arkistoäänitteiden itkuvirsien tunteisiin ja affektiivisuuteen väitöstutkimuksessaan. Työpari vie äänellä itkemistä nykyaikaisiin esitysympäristöihin ja -tilanteisiin. Tällaisia konteksteja ovat muun muassa sosiaaliset mediat ja muut sähköiset kanavat, konsertit ja yksityiset tilanteet. Itkujen aiheina ovat yksityisten surujen ja huolten lisäksi muun muassa, yhteiskunnalliset ja globaalit aiheet kriiseistä politiikkaan. Teemat nousevat yhtäältä Kuittisen kokemuksista taiteilijana ja itkuvirsien opettajana, toisaalta niiden muodostumiseen vaikuttaa Silvosen aiempi itkuvirsitutkimus.

\section{Uusia tutkimisen tapoja etsimässä}

Hankkeessa etsimme myös toimintatapoja ja käytäntöjä siihen, miten tieteen ja taiteen traditiot tukevat toisiaan ja tuottavat yhdessä uutta. Tutkija-taiteilija-työparien työskentelyn 
tavoitteena on syventää tutkimuksen tuloksia ja avartaa kummankin osapuolen toimintaa: täydentää taiteilijan refleksiivistä kokemuksellista ja tiedollista puolta sekä laventaa tutkijoiden näkökulmia ja työkaluja. Työskentelytavan uskomme varmistavan erilaisten ja uusien näkökulmien esille pääsemisen ja lisäksi se valottaa itkuperinteen moninaisuutta paremmin kuin mihin kumpikaan puoli yksistään yltäisi.

Tutkija-taiteilija-työparien lisäksi hanke tarjoaa alustan hankkeen tutkijoiden keskinäiselle yhteistyölle, samalla kun se mahdollistaa taiteilijoiden yhteisen toiminnan. Yhteisen työskentelyn lisäksi kaikki tutkijat ja taiteilijat tekevät työtään myös itsenäisesti.

Kyynelkanavat-hankkeen koti on Itä-Suomen yliopiston Yhteiskuntatieteiden ja kauppatieteiden tiedekunnassa Karjalan tutkimuslaitoksella, joka tekee monitieteistä humanistista ja yhteiskuntatieteellistä tutkimusta. Hankkeessa tehdään yhteistyötä myös Äänellä itkijät ry:n kanssa.

Kyynelkanavat-hankkeen verkkosivusto: https://sites.uef.fi/kyynelkanavat/

\section{Lähteet}

Fenigsen, Janina ja James M. Wilce. 2012. "Authenticities: A Semiotic Exploration." Semiotic Inquiry 32(1-3): 103-22. http://dx.doi.org/10.7202/1027774ar

Honko, Lauri 1963. "Itkuvirsirunous." Teoksessa Suomen Kirjallisuus I: Kirjoittamaton Kirjallisuus, toimittanut Matti Kuusi, 81-128. Helsinki: Suomalaisen Kirjallisuuden Seura.

Jetsu, Laura. 2013. "Elämän päättyminen." Teoksessa Juuret karjalassa. Karjalainen perhe perinteiden ja muutosten äärellä, 389-467. Helsinki: Tammi.

Konkka, Unelma. 1985. Ikuinen ikävä: Karjalaiset riitti-itkut. Helsinki: Suomalaisen Kirjallisuuden Seura.

Nenola-Kallio, Aili. 1982. Studies in Ingrian Laments. Folklore Fellows' Communications 234. Helsinki: Suomalainen tiedeakatemia.

Stepanova, Eila. 2014. Seesjärveläisten itkijöiden rekisterit: Tutkimus äänellä itkemisen käytänteistä, teemoista ja käsitteistä. Helsinki: Suomen Kansantietouden Tutkijain Seura.

Tenhunen, Anna-Liisa. 2006. Itkuvirren kolme elämää. Helsinki: Suomalaisen Kirjallisuuden Seura.

Wilce, James M. 2009. Crying Shame: Metaculture, modernity, and the exaggerated death of lament. Chister: Wiley-Blackwell.

FT, dos. Elina Hytönen-Ng (https://orcid.org/0000-0003-4082-2490) on musiikillisiin kokemuksiin erikoistunut kulttuurintutkija, joka työskentelee Karjalan tutkimuslaitoksella Itä-Suomen yliopistossa. TM Riikka Patrikainen tekee perinteentutkimusta ja ortodoksisen kirkkomusiikin tutkimusta yhdistävää väitöskirjaansa Itä-Suomen yliopistossa. FM Viliina Silvonen (https://orcid.org/0000-0002-7191-4956) viimeistelee folkloristiikan väitöskirjaansa Helsingin yliopistossa. 